\title{
非晶性高分子材料のヒステリシスに関する分子動力学的研究*
}

屋 代 如 月*1, 内 藤 正 登*2
皆川康 久*3, 冨 田 佳 宏*4

\section{A Molecular Dynamics Study on Hysteresis of Amorphous Polymers}

\author{
Kisaragi YASHIRO*5, Masato NAITO, \\ Yasuhisa MINAGAWA and Yoshihiro TOMITA \\ ${ }^{* 5}$ Faculty of Engineering, Kobe University, \\ 1-1 Rokkodai-cho, Nada-ku, Kobe-shi, Hyogo, 657-8501 Japan
}

\begin{abstract}
For a new insight on the mechanism of hysteresis of polymers, several molecular dynamics simulations are conducted on an amorphous polyethylene under cyclic deformation. Each role of the bond stretch, bending, torsion and van der Waals is investigated in detail, revealing that the bond stretch and van der Waals dominate the hysteresis in the cyclic deformation. In the 1st cycle, or the "pre-stretching", the trans nodes increase to orient the molecular chains in loading direction. However, the trans $\Rightarrow$ gauche transition takes place during the unloading, resulting in the "curled" chain structure which has more gauche nodes than the initial configuration. In the 2nd cycle up to the maximum strain of the 1st cycle, the gauche $\Leftrightarrow$ trans change occurs in the "pseudo reversible" manner among the gauche nodes introduced in the 1st cycle. When the polyethylene is elongated in the 2nd cycle beyond the maximum strain, the dihedral nodes with high torsional energy, which are not in the trans nor gauche angles, decrease to lead the increase of trans nodes. This suggests that the overloading orients the entangled chains in loading axis, resulting in the dissociation of the chain entanglements.
\end{abstract}

Key Words: Molecular Dynamics Simulation, Polymer, Rubber, Hysteresis, Mullins Effect

\section{1. 緒 言}

ゴムに特徵的な機械的性質として “Mullins 効果 ${ }^{(1)} "$ がある. ゴムを伸び $\alpha_{m}=L / L_{0}\left(L_{0}, L\right.$ はそれぞれ引 張前と引張後のゴム長さ) まで引っ張った後, 除荷す る (予備伸張するという). 予備伸張されたゴムを再度 引つ張ると, 応力ーひずみ曲線は予備伸張時のそれと は一致せず低い応力を示す（図 1). 一方, 伸び $\alpha_{m}$ を 超えてさらに引っ張ると, 本来描くべき曲線に一致し, 次の引っ張り時にはその伸びまで低い応カーひずみ曲 線を描く．この効果は, 純ゴムにはほとんど見られず, 加硫処理によりカーボンブラック (CB) が充填された ゴムにおいて顕著となる. Mullins 効果の発現メカニ ズムとして，充填粒子間の分子鎖の切断 ${ }^{(2)}{ }^{(3)}$, 充填 粒子／ゴム界面の剥離 ${ }^{(4)}$, 分子鎖の滑りに伴う架橋点 数変化と周囲の分子鎖間の摩擦 ${ }^{(5)}$, 数珠状に連なった $\mathrm{CB}$ の切断 ${ }^{(6)}$ など様々なメカニズムが考えられている. しかしながら，いずれも現象論的アプローチによるも

\footnotetext{
* 原稿受付 2005 年 6 月 17 日.

*1 正員, 神戸大学工学部（ 657-8501 神戸市灘区六甲台町 11).

*2 正員, SRI 研究開発(株) (-651-0071 神戸市中央区筒井町 2-1-1).

*3 SRI 研究開発(株)

*4 正員, 神戸大学大学院自然科学研究科.

E-mail : yashiro@mech.kobe-u.ac.jp
}

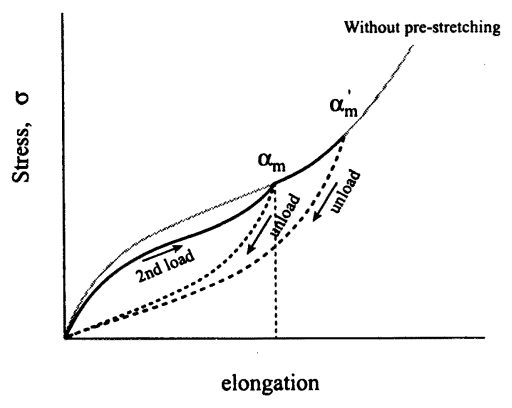

Fig. 1 Schematic of the Mullins effect.

のであり、ゴム内部で生じている現象を真に反映させ たモデルがいずれか，現時点では実験的手法により検 証するすべがない，さらには，Mullins 効果を議論す る前に, ゴムのヒステリシスそのものについて, 十分 に解明されているとは言い難い. Voigt モデルおよび Maxwell モデルといった粘弾性挙動を考慮するモデル (7)の組み合わせでゴムのヒステリシスを表現できるこ とは知られているが, 粘弾性をもたらす内部の分子鎖 挙動については十分な検証がなされていないように思 
われる.

著者らのグループでは, 分子鎖の架橋点変化を考 慮した非アフィン分子鎖網目モデル ${ }^{(8)}$, および, 周囲 の分子鎖との摩擦によって生じる粘性抵抗を考慮する reputation モデル(9)によって表現した粘弾性構成式を 用いて，均質化法を用いた有限要素シミュレーション を行い, CB 充填ゴムのヒステリシスに及ぼす架橋点 数変化や粘弾性の効果を詳細に検討してきた ${ }^{(10)}$. し かしながら，先述のように現象論的アプローチでは， ゴムのヒステリシスを再現できても内部で生じている メカニズムを解明することはできない，提案したモデ ルに対して確たるバックボーンを得るためには分子論 的アプローチが必須である．そこで本論文では，著者 らのグループでこれまで行ってきた非晶性高分子の分 子動力学シミュレーション (11) (13)を援用し, ヒステ リシスを生じる分子鎖メカニズムに迫る.

ゴム (エラストマー) に関する分子動力学シミュレー ションとして, ポリブタジェンン (14) (16), ポリイソプ レン(17) (19), ポリイソブチレン ${ }^{(20)}$ を対象とした研究 があるが，本論文ではゴム分子鎖ではなく最も単純な 高分子であるポリエチレンを対象とする. 微視的メカ ニズムの素過程を抽出するには, 最初から実現象に近 づけたモデルを用いるよりも，簡略化したモデルを用 いる方が都合がよい. 2 重結合のないポリエチレンの 挙動を調べることで，ゴム分子鎖のシミュレーション を行う際に, 2 重結合部分の果たす役割などを明らか にできると考える.

\section{2. シミュレーション条件}

水素原子は陽に扱わずにメチレン基 $\left(-\mathrm{CH}_{2}{ }^{-}\right)$を 1 粒子として扱う United Atom Model を用いる. 粗視 化した粒子に対する分子鎖内ボンド結合ならびに分子 鎖間 van der Waals 相互作用は, 桑島ら ${ }^{(21)}$ に従い以 下のポテンシャル関数および表 1 に示すパラメータを 用いた。詳細については前報 ${ }^{(11)}$ を参照されたい.

$$
\begin{aligned}
& E_{\mathrm{tot}}=E_{\mathrm{bs}}(r)+E_{\mathrm{be}}(\theta)+E_{\mathrm{to}}(\phi)+E_{\mathrm{vw}}(\bar{r}) \\
& E_{\mathrm{bs}}(r)=\sum\left\{k_{r}\left(r-r_{0}\right)^{2}\right\} \\
& E_{\mathrm{be}}(\theta)=\sum\left\{k_{\theta}\left(\theta-\theta_{0}\right)^{2}\right\} \\
& E_{\mathrm{to}}(\phi)=\sum\left\{V_{1} \cos \phi+V_{2} \cos 2 \phi+V_{3} \cos 3 \phi\right\}(4) \\
& E_{\mathrm{vw}}(\bar{r})=\sum\left\{A(\bar{r})^{-12}-C(\bar{r})^{-6}\right\}
\end{aligned}
$$

$20 \mathrm{~nm} \times 20 \mathrm{~nm} \times 20 \mathrm{~nm}$ の立方体セル中に, 前報(11) と同様に乱数を用いて多数のランダムコイル状分子鎖 を成長させ，ポリエチレンアモルファス構造を作成し た. ここで, 平均分子鎖長を 300 , 標準偏差を 50 に
Table 1 Potential parameters for polyethylene.

\begin{tabular}{ccl}
\hline$r_{0}$ & 0.1533 & $(\mathrm{~nm})$ \\
$k_{r}$ & $1.373 \times 10^{5}$ & $\left(\mathrm{~kJ} /\left(\mathrm{mol} \cdot \mathrm{nm}^{2}\right)\right)$ \\
$\theta_{0}$ & 113.3 & $(\mathrm{deg})$ \\
$k_{\theta}$ & 374.7 & $\left(\mathrm{~kJ} /\left(\mathrm{mol} \cdot \mathrm{rad}^{2}\right)\right)$ \\
$V_{1}$ & 3.935 & $(\mathrm{~kJ} / \mathrm{mol})$ \\
$V_{2}$ & 2.177 & $(\mathrm{~kJ} / \mathrm{mol})$ \\
$V_{3}$ & 7.786 & $(\mathrm{~kJ} / \mathrm{mol})$ \\
$A$ & $2.972 \times 10^{19}$ & $\left(\mathrm{~kJ} / \mathrm{mol} \cdot \mathrm{nm}^{12}\right)$ \\
$C$ & $6.907 \times 10^{9}$ & $\left(\mathrm{~kJ} / \mathrm{mol} \cdot \mathrm{nm}^{6}\right)$ \\
\hline
\end{tabular}

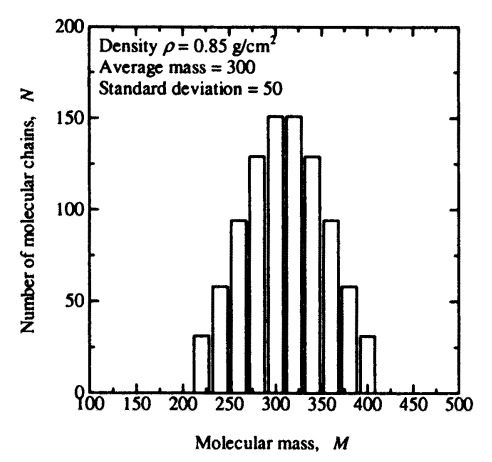

Fig. 2 Distribution in molecular mass.

設定し，分子鎖長の分布が正規分布となるように分子 鎖成長をコントロールした. 図 2 に作成した分子鎖構 造の分子量分布を示す.なお，ここではメチレン粒子

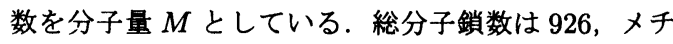
レン粒子総数は 277,337 である. 作成した初期構造に ついて，セル端面より $1 \mathrm{~nm}$ 以内の粒子の運動を，壁 面内に拘束する境界条件 (模式図 3) の下で 1000fs の 分子動力学計算を行って構造緩和させた. 分子動力学 における積分の時間ステップは $0.1 \mathrm{fs}$ である．温度は $300 \mathrm{~K}$ とし, 速度スケーリングにより制御した.

その後, セルの上下方向に引張ひずみを与えるシ ミュレーションを行った。 まず, 1 サイクル目として $\varepsilon_{z z}=0.5$ まで一定ひずみ速度 $\dot{\varepsilon}_{z z}=1.0 \times 10^{11} / \mathrm{s}$ で 引張り，同一ひずみ速度で除荷するシミュレーション を行った。ここで,ひずみは初期緩和計算後のセル 長さを基準とする工学ひずみである. 粒子の $z$ 座標 を $z=z \times\left(1+\varepsilon_{z z}+\Delta \varepsilon_{z z}\right) /\left(1+\varepsilon_{z z}\right)$ と毎ステッ プスケールすることによりひずみを与える.ここで, $\Delta \varepsilon_{z z}=1.0 \times 10^{-5}$ である.1 サイクルの変形の後, (1) $\varepsilon_{z z}=0.5$, (2) $\varepsilon_{z z}=0.3$, (3) $\varepsilon_{z z}=0.8$, の 3 つの最大ひずみまで引張/除荷する 2 サイクル目のシ ミュレーションをそれぞれ行った. ひずみ速度はいず れも 1 サイクル目と同じである. なお，本ポテンシャ 


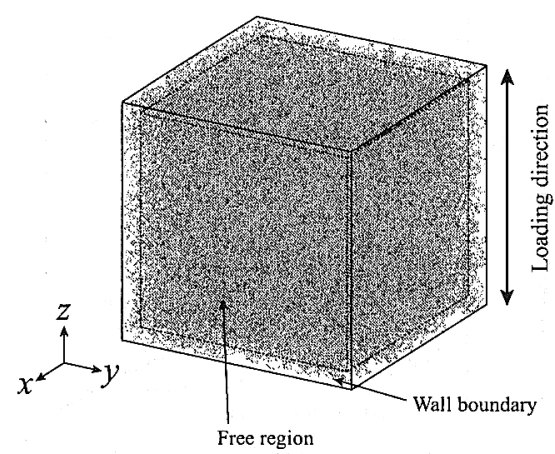

Fig. 3 Wall boundary and loading direction.

ルを用いた引張シミュレーション (11) (13) ではひずみ $\varepsilon=0.02$ 程度で非弾性変形を生じており，上記の最 大ひずみはいずれもそれに比べて十分大きい，全ての シミュレーションにおいて温度は $300 \mathrm{~K}$ とし，速度ス ケーリングにより制御した。

\section{1 サイクル目のヒステリシス}

$3 \cdot 1$ 応カーひずみ関係 1 サイクル目の変形シ ミュレーションにより得られた応力ーひずみ曲線を図 4 に示す，図には引張方向の応力 $\sigma_{z z}$ だけでなく，横方 向の応力 $\sigma_{x x}$ および $\sigma_{y y}$ もあわせて示している，応 力は，図 5 に模式的に示すように，可動部分の各原 子位置において，正方向に作用する力（切断法による 内力）を加算することによりセルに働く $x, y, z$ 方向の 軸力を求め, 可動部分の体積で除すことにより評価し た。設定した密度 $0.85 \mathrm{~g} / \mathrm{cm}^{3}$ では，基準状態におい $\tau \sigma_{x x} \approx \sigma_{y y} \approx \sigma_{z z} \approx 150 \mathrm{MPa}$ の静水圧圧縮状態で ある、ひずみの増加とともに引張方向応力は非線形に 増加吋る。ここで，壁面境界により Poisson 収縮を拘 束しているため, 横方向にも引張りが生じ応力が増加 している，なお，初期圧縮応力ならび横方向の変形 拘束が以降の議論に影響を及ぼさないことは，本研究 の後に行ったポリエチレンとポリブタジエンのシミュ レーションで確認している(22).ひずみ 0.5 において， ひずみ増分 $\Delta \varepsilon_{z z}$ を負にすると極めて短時間 ( $\left.50 \mathrm{fs}\right)$ に応力が約 $100 \mathrm{MPa}$ から約 $45 \mathrm{MPa}$ まで減少した，横 方向の応力も変位の反転時に急激に減少するが，その 幅は小さく，除荷時の応力ーひずみ曲線は $\sigma_{x x}$ および $\sigma_{y y}$ の方が $\sigma_{z z}$ より高い応力を示す. また， $\varepsilon_{z z}=0$ ま で戻した際に，横方向応力は初期状態とほぼ同じ值と なったのに対し，負荷方向の応力は $-206 \mathrm{MPa}$ と初期 状態より大きな圧縮応力を示している．ただし，この

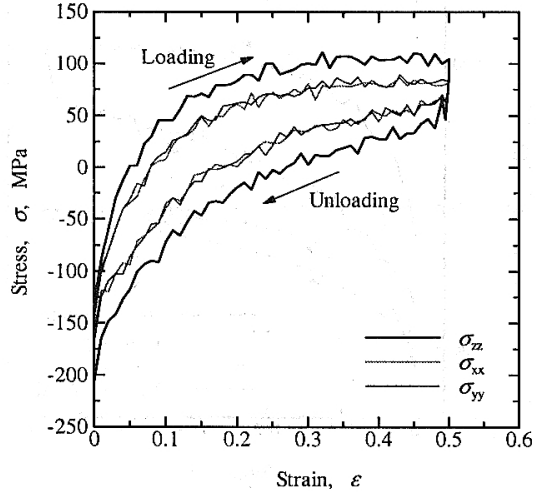

Fig. 4 Stress-strain curves (1st cycle).

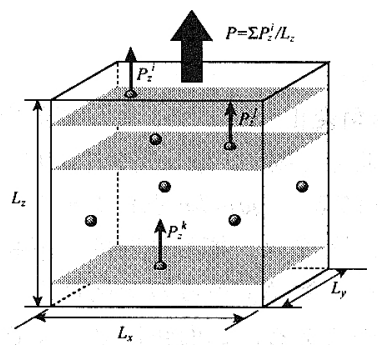

Fig. 5 Evaluation of stress on the simulation cell.

忘力は $\varepsilon_{z z}=0$ で保持した場合のものではなく，動的 な除荷過程で $\varepsilon_{z z}=0$ に達した瞬間におけりる值である。

3.2 ポテンシャル成分毎の評価 原子に作用 する力は式 (1) の空間微分から得られるので, 応力 を評価する際，式 (2)〜 (5) から bond stretch(結合 長), bending(結合角), torsion(二面角) およびvan der Waalsの奇与を明らかにすることができる.なお，本論 文ではポテンシャル成分そのものは bending, torsion などの英語で表すものとし，結合角 $\theta$ や二面角 $\phi$ な どのボンドの形状を表す場合は日本語を用いるものと する. 図 6 は $\sigma_{z z}$ の変化を, ポテンシャル成分の奇与. 毎に分離して示したものである. 図 4 のヒステリシ スのほとんどは bond stretch が担っていることがわ かる. 次に大きく寄与しているのはvan der Waals で ある. van der Waals の寄与は引張によって零に漸近 しており，ヒステリシスには圧縮としてのみ寄与する ことがわかる. bending は負荷時および除荷時にそれ ぞれわずかに一定の正および負の応力を担い，bond stretch と同様に負荷反転時に急速な減少を示してい る. torsion は変形中常にほぼ零であり, 系の忘力変 


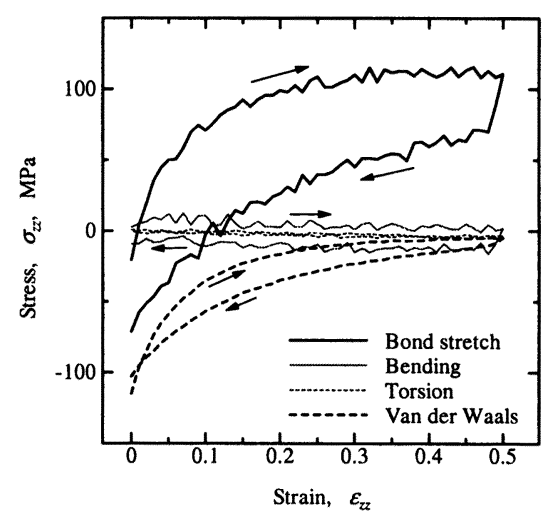

Fig. 6 Components of the tensile stress of bondstretch, bending, torsion and van der Waals.

化に寄与しない.

$3 \cdot 3$ 二面角变化 1 サイクル変形中のすべての 二面角 $\phi$ の変化を調べ, 最安定角 $\left(180^{\circ}\right.$, trans 点) と 準安定角 $\left( \pm 67.5^{\circ}\right.$, gauche 点) にあるノード数の変 化を調べた. 図 7 は, 横軸に時間, 縦軸に初期構造 におけるノード数 $N_{0}$ からの変化量 $N-N_{0}$ をとっ て示したものである. 二面角は $0^{\circ} \leq \phi \leq 180^{\circ}$ の 範囲で評価し， $160^{\circ} \leq \phi \leq 180^{\circ}$ のものを trans ノード, $47.5^{\circ} \leq \phi \leq 87.5^{\circ}$ のものを gaucheノー ド，そのほかのものを高いエネルギーを持つノード (以下では high energy ノードと称する) としている. $t=0 \sim 5000$ fs が負荷過程, $t=5000 \sim 10000$ fs が除 荷過程に対応する. 引張初期には, high energyノー ドが急減し, それに対応して gauche 点が増加してお り, 引っ張りを駆動力として内部が構造緩和されたこ とを示している. 一方, 応力ーひずみの勾配が緩やか になる $\varepsilon_{z z}=0.15(t=1500 \mathrm{fs})$ 近傍で, gaucheノー ドの増加, high energy ノードの减少が止まり, 以降 はgaucheノードが減少している. transノードは最大 ひずみまで単調に増加しており, 引張過程において直 線状の部分が増えていることを示唆している.

$t=5000 \mathrm{fs}$ でひずみ増分 $\Delta \varepsilon_{z z}$ が反転されると, transノードが急减し，それに対応して gaucheノ一 ドが急増する. すなわち, 除荷過程において trans $\Rightarrow$ gauche 遷移が生じ, 分子鎖に多数の折れ曲がりが導 入されている. $t=10000 \mathrm{fs}$ すなわち $\varepsilon_{z z}=0.0$ まで 戻った時点で, 初期構造よりも gaucheノードが多く, trans ノードが少ない状態になっている. すなわち, 1 サイクル変形後の構造は, 初期構造よりも分子鎖の “たるみ”が多い構造となっていることが示唆される.

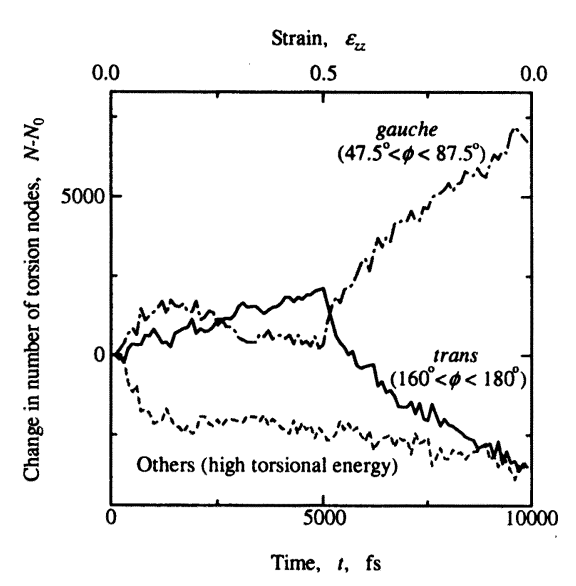

Fig. 7 Change in the number of trans, gauche and high torsional energy nodes (1st cycle).

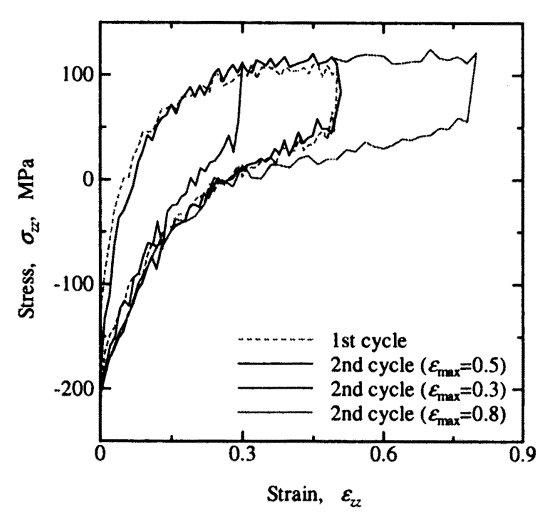

Fig. 8 Stress-strain curves (2nd cycle).

\section{2 サイクル目のヒステリシス}

$4 \cdot 1$ 応カーひずみ関係 2 サイクル目の応力一 ひずみ曲線を図 8 に示す. 再負荷時の経路はほぼ 1 サ イクル目のそれと一致する. 1 サイクル目と同じ最大 ひずみ $\varepsilon_{z z}=0.5$ までの引張・除荷の場合, ほほ 1 サイ クル目と同一のヒステリシスを示す. 特に, 除荷過程 はほとんど同じ経路をたどる. $\varepsilon_{z z}=0.3$ までの引張・ 除荷の場合, 変位反転時に応力は急减するが, 1 サイ クル目の除荷経路までは低下しない.このため, 1 サ イクルとは異なった除荷経路を描くが, $\varepsilon_{z z}<0.15$ で は 1 サイクル目のそれに一致する. $\varepsilon_{z z}=0.8$ までの 引張・除荷では, やはり変位反転時に応力が急减した 後, 1 サイクル目の除荷経路より低い応力を示しなが ら 0 に漸近し, 応力がほぼ 0 となる点で 1 サイクル目 の除荷経路とほほ一致した. 


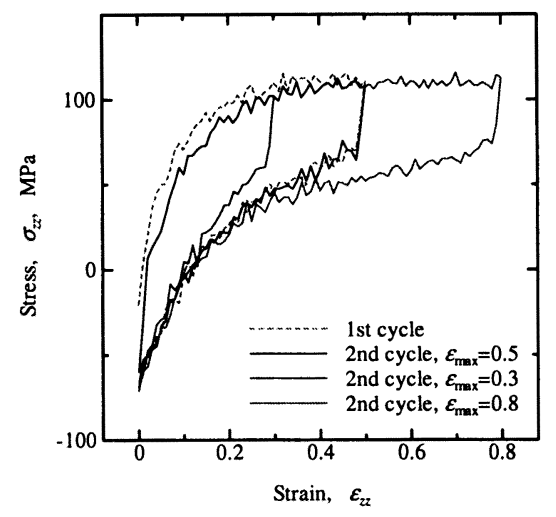

Fig. 9 Tensile stress of bond stretch (2nd cycle).

\section{2 ポテンシャル成分毎の評価 前節と同様, ポ} テンシャル毎の応力変化を 2 サイクル目について調べ た. 図 9 に bond stretch による応力寄与, 図 10 に van der Waalsによる応力寄与を示す. bending, torsion に ついてはいずれも 1 サイクル目とほとんど違いがない ため省略する. 再負荷時, bond stretch は 1 サイクル目 よりわずかだが低い応力を示している. 一方, van der Waals は 1 サイクル目より上側（低圧縮応力）の経路 をたどる. これらを足し合わせると, 結果として, 図 8 のように忘力は 1 サイクル目とほぼ同一となる. 再負 荷時に bond stretch の応力が低下し, van der Waals の応力が低圧縮側にシフトした理由については後で考 察する. 同一ひずみの繰り返しの場合 $\left(\varepsilon_{z z}=0.5\right)$, 除 荷曲線は bond stretch, van der Waals ともほとんど 同じ経路をたどっていることがわかる．また，最大ひ ずみを変化させた場合の bond stretch, van der Waals のヒステリシスの変化は図 8 と一致している.

4.3 二面角变化 2 サイクル変形中における trans, gauche および high energy ノード数の変化を 図 11 に示す. 図 7 と同じように初期状態における ノード数 $N_{0}$ からの変化で表しており, $t=10000 \mathrm{fs}$ におけるノード数が 1 サイクル終了後の值である。ひ ずみ $\varepsilon_{z z}=0.3,0.5,0.8$ における変位反転はそれぞれ $t=13000 \mathrm{fs}, 15000 \mathrm{fs}, 18000 \mathrm{fs}$ の点に対応する. なお, transおよび gauche のグラフは横軸のスケールが同一 であるが, high energy ノードについては 2 倍に拡大し て表示している. 再負荷時, いずれも gaucheノードが 减少し transノードが増加しており, gauche $\Rightarrow$ trans 遷 移が生じて直線状部分が増加していることが示唆され る. 再負荷初期を詳細に観察すると, gaucheノードの 减少に対して, transノードの増加割合の方が大きい. このとき, high energy ノードが減少していることから,

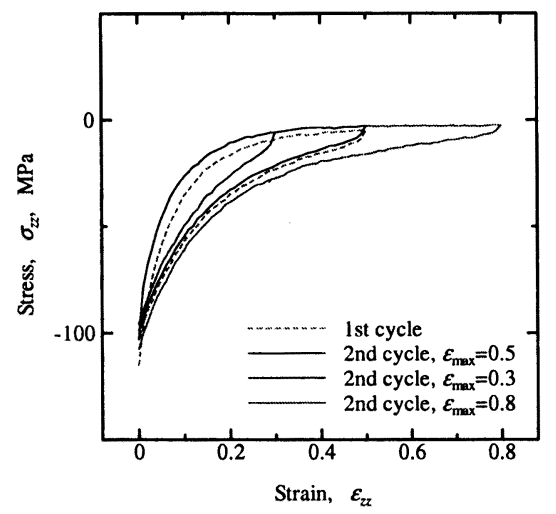

Fig. 10 Tensile stress of van der Waals (2nd cycle).

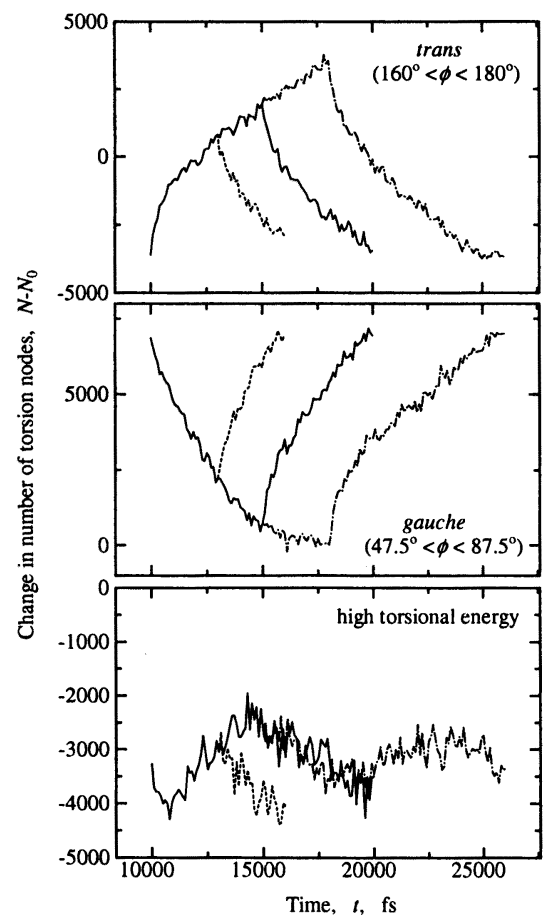

Fig. 11 Change in the number of trans, gauche and high torsional energy nodes (2nd cycle).

引張による構造変化が少しではあるが生じていること がわかる．変位を反転すると trans $\Rightarrow$ gauche 遷移を生 じ, 増加した transノード数, 减少した gaucheノード 数はいずれも 1 サイクル終了後とほぼ同じ值に戻る. 最大ひずみ 0.3 および 0.5 の変形では, high energy 
ノードも再負荷時に增加・変位反転で減少し，ほぼ元 の值に戻る.このことから，1サイクル目のひずみを 超えない範囲での繰り返し変形では，1サイクル目に 導入された分子鎖構造の中で, gauche $\Leftrightarrow$ trans 遷移が “見かけ上”可逆的に生じていることが示唆される. 一 方, 最大ひずみ 0.8 の場合, $t=15000 \mathrm{fs}$ を超えて引張 を継続しているにもかかわらず, $t=15000 \sim 18000 \mathrm{fs}$ において high energy ノードが減少する.このとき， trans ノードは $\varepsilon_{z z}=0.5$ までと変わらず增加してい るのに対し, gaucheノードの減少割合は低下してい る.これは，1サイクル目に導入された分子鎖の “た るみ”が伸びきり， $\varepsilon_{z z}=0.5 \sim 0.8$ の引つ張りによっ て, high energy ノードから trans ノードへの構造変化 を生じたことを示している. なお, high energy ノー ドは, 分子鎖が絡み合って変形しにくい部分と考え ることができる. $\varepsilon_{z z}=0.3,0.5$ の変形における high energy ノードの增加・減少は, 1 サイクル目に導入さ れた構造における絡み点近傍のノードを反映している ものと考えられる.すなわち，ひずみの增加とともに， 変形しにくい絡み点近傍の二面角が trans, gauche 点 以外の角度を取らざるを得ず, high energy ノードが 增加するが, 絡み点近傍の構造変化を生じる前に除荷 されることにより high energy ノードは解消される. 一方, $\varepsilon_{z z}=0.8$ の変形では, これらのノードが減少 し trans ノードに変化しているので, 過負荷によって 絡み点の構造変化もしくは絡み点が解消したことを示 唆している.

\section{5. 考察}

$5 \cdot 1$ bond stretch のヒステリシス 引張変形 を与えるとまず bond stretch と bending が応力增加を 担い，限界に達すると二面角の回転による非弾性変形 を生じる ${ }^{(11)}$. 引張二除荷における変位反転時の bond stretch および bending の急減は, 弾性変形に相当す るこれらのノードの緩和によるものである. 図 8 およ び図 9 において, 変位反転時の応力急减がほぼ等しい ことも，これらが弾性変形であることを意味する.

引張 ・除荷時の bond stretch の応力曲線は, 引張方 向に平行なボンド数で説明される. 図 12 は, 引張軸と なす角度が $20^{\circ}$ 以下のボンド数の変化を, 初期状態か らの変化量 $N-N_{0}$ で示したものである. 引張時には trans ノードが増えて直線状部分が増加することはす でに述べたが，図からわかるように，これが分子鎖の 引張方向一の配向に対応しており, 引張軸に平行なボ ンドの数が增える. このため, bond stretch の担う応 力が増加する. 1 サイクル終了時は, 先述したように

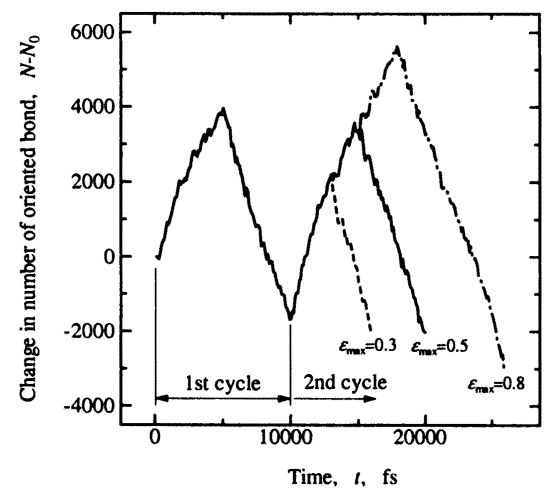

Fig. 12 Change in number of bonds oriented in tensile axis.

初期状態より分子鎖が “たるむ”ため, 初期状態より 引張軸に平行なボンド数が堿少する.このため, 2 サ イクル目の引張において, 同一ひずみで bond stretch が担う応力が減少する. 図 13 に 1 サイクル目の変形 における，1本の分子鎖の引張一除荷時の変化の例を 示す. 図中には着目している分子鎖粒子のカットオフ 半径内に存在寸る他の分子鎖の粒子も合わせて表示し ている. 除荷後の分子鎖は変形前の形状に近いものと なるが, 矢印で示したように折れ曲がった部分が多数 導入されている.なお，図 12 において，同一ひずみ 範囲内での繰り返し $\left(\varepsilon_{z z}=0.3,0.5\right)$ では, 1 サイクル 終了時と 2 サイクル終了時の平行ボンド数がほぼ同じ なのに対し, $\varepsilon_{z z}=0.8$ の変形ではさらに减少してい る. したがって，次のサイクルでは bond stretch の担 う応力が减少するものと予想される.

$5 \cdot 2$ van der Waals のヒステリシス van der Waals のヒステリシスを明らかにするため, 各粒子を 中心にカットオフ半径 $\left(r_{\mathrm{cut}}=0.8 \mathrm{~nm}\right)$ 内にある近接 粒子数を調べ, 粒子質量の合計をカットオフ球体積で 除すことにより局所密度 $\rho^{\alpha}$ を求めた. 図 14 は最大 ひずみ 0.5 までの 2 サイクルにおける局所密度の平均 值 $\left(\bar{\rho}^{\alpha}\right)$ の変化である. なお， $\varepsilon_{z z}=0.0$ で設定密度 $0.85 \mathrm{~g} / \mathrm{cm}^{3}$ と一致しないのは壁面近傍の低密度部分に よる. 図より，除荷時は引張時よりも高密度となって いることがわかる.これは, 引張時の密度减少に対し て, 除荷時の密度增加に対する van der Waals の緩和 が遅れるためである．事実，ひずみ速度を大きくする と van der Waals のヒステリシスが圧縮側に大きくな ることを別のシミュレーションにより確認している. van der Waals を完全に緩和しながら行う静的な変形 


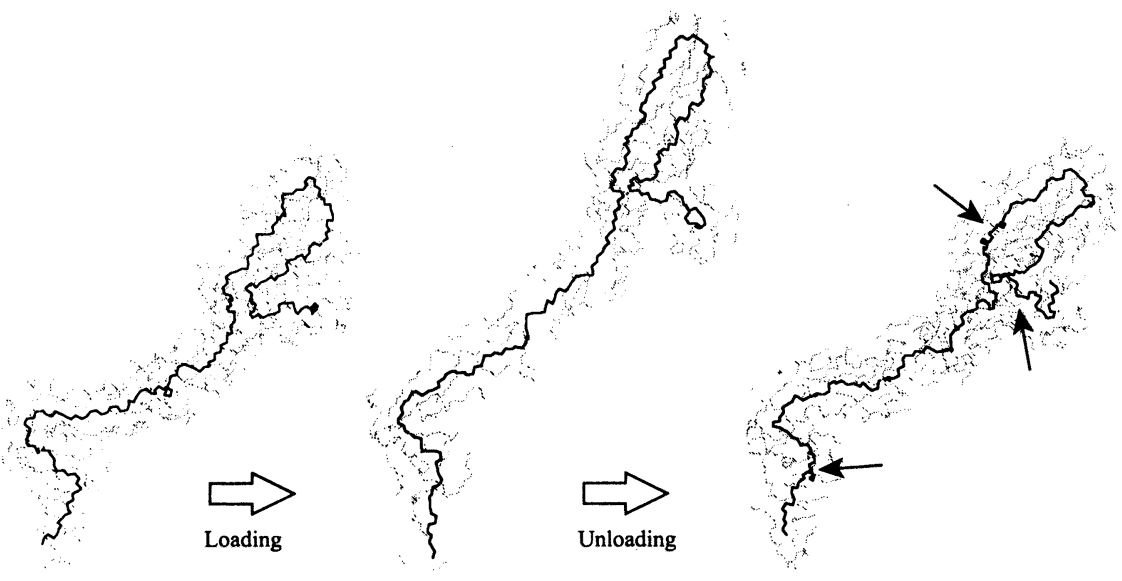

Fig. 13 Snapshots of a molecular chain under the 1st cycle.

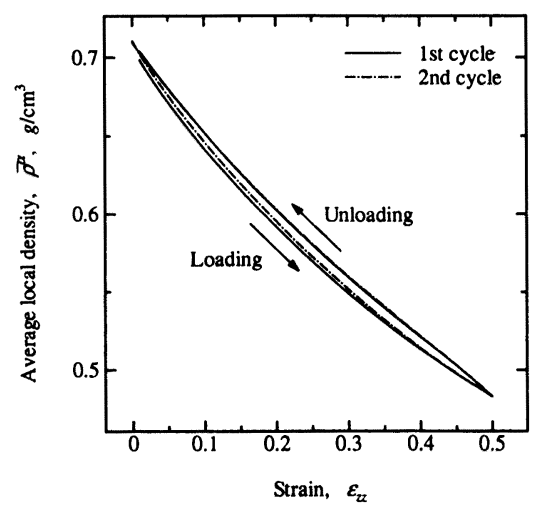

Fig. 14 Change in the average local density.

においては,このヒステリシスはなくなるものと推測 される.

このように, 1 サイクル目の van der Waals のヒス テリシスは平均局所密度の変化により説明されるが, 図 10 において 2 サイクル目の van der Waals の応力 が低圧縮側の経路を通った理由については図 14 では 説明できない. 図 15 に示すように, 1 サイクル引張, 1 サイクル除荷時, 2 サイクル引張時の $\varepsilon_{z z}=0.25$ に おける局所密度の分布を比較しても，1 サイクル引張 と 2 サイクル引張の分布には大きな違いはなく, むし ろ平均密度近傍のノードの割合が増加していることか ら，1サイクル目より 2 サイクル目において，圧縮応 力が大きくなる経路をとることになり矛盾する.これ は, 1 サイクル目の変形により “たるんだ” 分子鎖構造 となり, 同一密度であっても膨張に対する抵抗が小さ くなったためと考えられる.なお，2サイクル目の変

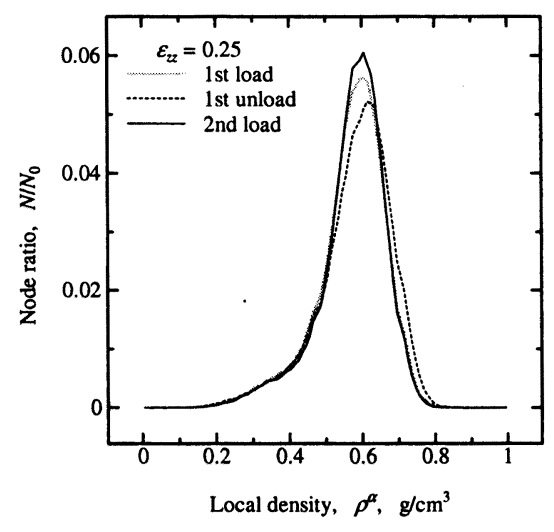

Fig. 15 Distribution in the local density.

形の局所密度分布は最大ひずみ $\varepsilon_{z z}=0.3,0.5,0.8$ い ずれもほとんど同一であった。しかしながら゙, 図 12 で述べたように, $\varepsilon_{z z}=0.8$ の過負荷を受けたものは, より “たるんだ”分子鎖が増えているものと推測され る. したがって, van der Waalsのヒステリシスもよ り低圧縮応力側を示すものと思われる.このような効 果を明らかにするためには，局所密度だけでなく分子 鎖の“たるみ”を表す物理量を明らかにする必要があ る. これについては今後の検討課題としたい.

\section{6. 結咅}

非晶性高分子のヒステリシスについて分子レベル から明らかにするため, アモルファスポリエチレンに 絽り返し変形を与える分子動力学シミュレーションを 行った. 得られた結果を要約して以下に示す.

(1) ヒステリシスにおける bond stretch, bending, 
torsion そして分子鎖間 van der Waals 相互作用の 果たす役割を調べ, bond stretch と van der Waals がヒステリシスを決定していることを明らかに した.

(2) 1 サイクル目の引張では trans ノードが増加 して直線状部分が増えるが，除荷過程におい て trans $\Rightarrow$ gauche 遷移が生じ, 初期状態よりも gauche ノードが多く trans ノードが少ない“たる んだ” 分子鎖構造になる.

(3) 1 サイクル目のひずみを超えない範囲での繰り返 し変形では，(2) で導入された分子鎖構造の中で gauche $\Leftrightarrow$ trans 遷移が可逆的に生じている.

(4) 2 サイクル目の変形が 1 サイクル目のひずみを超 える場合，(2) で導入された “たるんだ”分子鎖が 伸びきり, gauche, trans のいずれでもないエネル ギーの高い二面角が transノードへ構造変化する.

(5)（4）のエネルギーの高い二面角は，分子鎖が絡み 合って変形しにくい部分であり，2 サイクル目の 過負荷によって絡み点近傍の分子鎖が引張方向へ 配向し，絡み点が解消されたことを示唆している. 本研究により，ヒステリシスを生じる分子鎖の “た るみ”，すなわち変形を担う絡み点間の分子鎖につい て, 重要な知見が得られたものと考える. しかしなが ら, 複雑に発展する絡み点のメカニズムを特定するの は容易ではない. 今後, 分子量やひずみ速度を変えた シミュレーション，ならびにゴム分子鎖のシミュレー ションを行うことにより，ヒステリシスと絡み点の関 係が明らかになるものと期待される.

最後に, 本研究の一部は平成 16 年度科学研究費補 助金特定領域研究および若手研究 B の援助を受けた. ここに記して謝意を表する.

\section{文献}

(1) Mullins, L., Rubber Chem. Technol., 21, 281 (1948)

(2) Bueche, F., Rubber Chem. Technol., 34, 493(1961).

(3) Bueche, F., Rubber Chem. Technol., 35, 259(1965).

(4) O'Brien, J., Cashell, E., Wardell, G. E. and McBrierty, V. J., Macromolecules, 9, 653(1976).

(5) Dannenberg, E. M., Rubber Chem. Technol., 48, 410(1975).

(6) Payne, A. R. and Whittaker, R. E., Rubber Chem. Technol., 44, 440 (1971).

（7）村上謙吉, やさしいレオロジー, 産業図書 (1993).

(8) Tomita, Y., Adachi, T. and Tanaka, S., Eur. J. Mech., A/Solids, 16, 745(1997).

(9) Gennes, P. G., J. Chem. Phys., 55, 572 (1971).

(10) Tomita, Y. Lu, W., Naito, M. and Furutani, Y., Int. J. Mech. Sci., submitted.

（11）屋代 - 伊藤 - 富田，材料，Vol.53, No.1, 114 (2003).

(12) Yashiro, K. Ito, T. and Tomita, Y. Int. J. Mech. Sci., 45, 1863 (2004).

（13）屋代 ·伊藤 - 畐田, 機論, A70, 696 (2004).

(14) Smith, G. D., Paul, W., Monkenbusch, M. and Richter, D., Chem. Phys., 261, 61(2000).

(15) Gee, R. H., Henderson, D. and Wasan D. T., $J$. Coll. Inter. Sci., 232, 39(2000).

(16) Okada, O. and Furuya, H., Polymer, 43, 971(2002).

(17) Alvarez, F., Arbe, A. and Colmenero, J., Chem. Phys., 261, 47(2000)

(18) Kikuchi, H., Kuwajima, S. and Fukuda, M., Chem. Phys. Lett., 358, 466(2002).

(19) Alvarez, F., Arbe, A.,Colmenero, J., Zorn, R. and Richter, D., Comp. Mater. Sci., 25, 596(2002).

(20) Karatasos, K. Saija, F. and Rychkaert, J. P., Physica B, 301, 119(2001).

（21）桑島·野間・逢坂, 第 4 回計算化学シンポジウム, (1994), 53.

(22) K. Yashiro, M. Naito, Y. Minagawa and Y. Tomita, Proc. ICCES'05, (2005), in press. 